\title{
Nanocrystallization of Vanadium Borophosphate Glass for Improving the Electrical and Catalytic Properties
}

\author{
Su-Yeon Choi and Bong-Ki Ryu \\ Department of Material Science and Engineering, Pusan National University, Busan 609-735, Republic of Korea \\ Correspondence should be addressed to Bong-Ki Ryu; bkryu@pusan.ac.kr
}

Received 20 March 2015; Accepted 13 May 2015

Academic Editor: Min Liu

Copyright ( 2015 S.-Y. Choi and B.-K. Ryu. This is an open access article distributed under the Creative Commons Attribution License, which permits unrestricted use, distribution, and reproduction in any medium, provided the original work is properly cited.

\begin{abstract}
$75 \mathrm{~V}_{2} \mathrm{O}_{5}-10 \mathrm{P}_{2} \mathrm{O}_{5}-15 \mathrm{~B}_{2} \mathrm{O}_{3}$ ternary-system glasses were prepared and nanocrystallized to examine the catalytic effect and the variations in their structural and electrical properties. These glasses were annealed in a graphite mold above the glass transition temperature for $2 \mathrm{~h}$ and heat-treated at the crystallization temperature for 1,3 , and $5 \mathrm{~h}$. Fourier transform infrared spectroscopy (FTIR) was used to analyze the structural changes in the B-O bonds after nanocrystallization, while X-ray photoelectron spectroscopy (XPS) analysis showed a decrease in $\mathrm{V}^{5+}$ and an increase in $\mathrm{V}^{4+}$. X-ray diffraction (XRD) analysis of the structure array $\left(\mathrm{BO}_{3}+\mathrm{V}_{2} \mathrm{O}_{5} \leftrightarrow \mathrm{BO}_{4}+2 \mathrm{VO}_{2}\right)$ verified these inferred changes. Structural changes induced by the heat treatment were confirmed by analyzing the molecular volume determined from the sample density. Conductivity and catalytic effects were discussed based on the migration of vanadate ions with different valence states due to the increase in $\mathrm{VO}_{2}$ nanocrystallinity at $275^{\circ} \mathrm{C}$. Both conductance and the catalytic effect were higher after nanocrystallization at $275^{\circ} \mathrm{C}$ for $1 \mathrm{~h}$ compared to the annealed sample. Furthermore, compared to the sample heat-treated for $1 \mathrm{~h}$, the conductance and catalytic effect were increased and decreased, respectively, for samples nanocrystallized at $275^{\circ} \mathrm{C}$ for 3 and $5 \mathrm{~h}$.
\end{abstract}

\section{Introduction}

Vanadate glasses containing large amounts of $\mathrm{V}_{2} \mathrm{O}_{5}$ have multivalent ions of various states mixed in their structure. These glasses have been developed for infrared transmission and as atomic-exchange electroconductive glasses using electron conduction. Studies focusing on improving the performance of these glasses involve changing the electrical conduction properties through low valency $\left(\mathrm{V}^{4+}\right)$ to high valency $\left(\mathrm{V}^{5+}\right)$ metal-ion electron hopping [1], changing the catalytic properties for the oxidation reaction by altering the valency change between $\mathrm{V}^{4+}$ and $\mathrm{V}^{5+}$ [2], and examining the correlation between the glass composition and its characteristics while focusing on the type and condition of $\mathrm{V}$ ions or the type and the amount of alkali or alkaline earth metals [3-7].

In 2012, we substituted $\mathrm{B}_{2} \mathrm{O}_{3}$ for $\mathrm{P}_{2} \mathrm{O}_{5}$ to improve the chemical resistance and electrical conductivity of vanadium phosphate-based glasses, and we were able to investigate the significance of the correlation between the resulting structure and the electrical, thermal, and chemical properties
[6]. However, the effect of the substitution was insignificant. Moreover, the analysis of the catalytic activity of the oxidation reaction, which is characteristic of $\mathrm{V}_{2} \mathrm{O}_{5}$, with respect to the vanadate glass was insufficient. On the other hand, if vanadate glass is crystallized and the structure becomes denser, electron tunneling in the glass would occur with a higher frequency [8]. This behavior leads to frequent valency changes in the $\mathrm{V}$ cation. It is hypothesized that this change influences the change in the catalytic effect and electrical conductivity. In particular, if the nanocrystalline phases are generated, the specific surface area of the crystalline phases will be maximized. So, property changes due to crystallization appear to be more prominent.

In this study, $\mathrm{P}_{2} \mathrm{O}_{5}$ was used as a glass former, to which $\mathrm{V}_{2} \mathrm{O}_{5}$ or other metal oxides are added in order to achieve $\mathrm{V}_{2} \mathrm{O}_{5}$-like characteristics. We maximized the electrical conductivity and catalytic properties of $\mathrm{V}_{2} \mathrm{O}_{5}-\mathrm{B}_{2} \mathrm{O}_{3}-\mathrm{P}_{2} \mathrm{O}_{5}$ ternary glass by maximizing the amount of the substitute $\left(\mathrm{B}_{2} \mathrm{O}_{3}\right.$ for $\left.\mathrm{P}_{2} \mathrm{O}_{5}\right)$ to form $75 \mathrm{~V}_{2} \mathrm{O}_{5}-15 \mathrm{~B}_{2} \mathrm{O}_{3}-10 \mathrm{P}_{2} \mathrm{O}_{5}$ ternary glass. It was confirmed that nanocrystallizing this ternary 


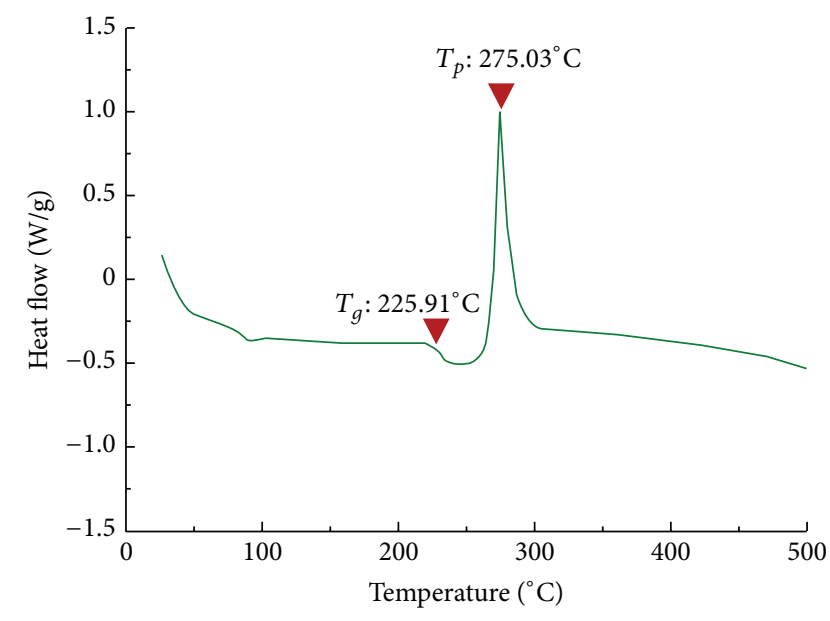

(a)

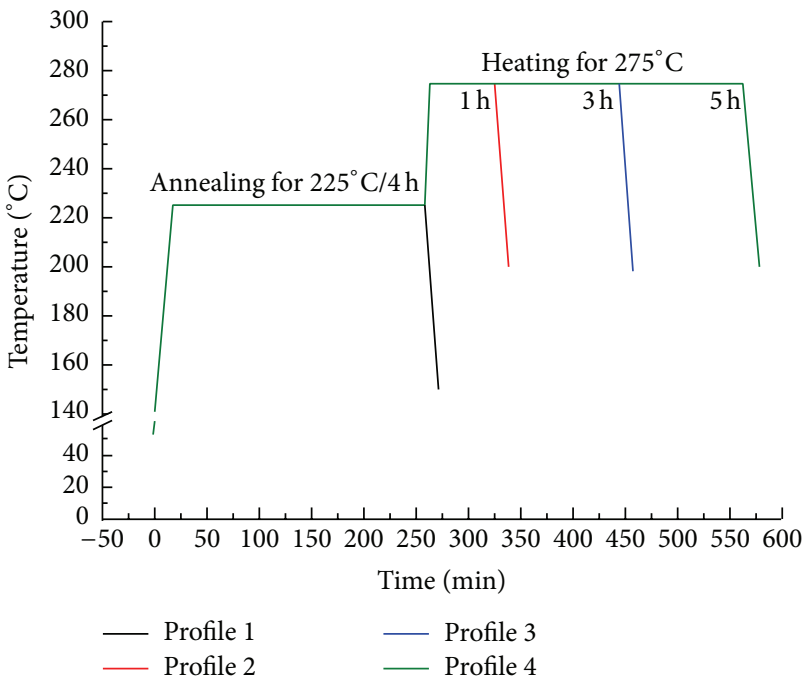

(b)

FIGURE 1: Differential scanning calorimetry (a) and resulting heat-treatment profile (b) for all the $\mathrm{V}_{2} \mathrm{O}_{5}$-based glasses used in this study.

glass produces $\mathrm{VO}_{2}\left(\mathrm{VO}_{4}\right), \mathrm{V}_{2} \mathrm{O}_{5}\left(\mathrm{VO}_{5}\right)$, and $\mathrm{B}_{2} \mathrm{O}_{3}\left(\mathrm{BO}_{4}\right)$ crystalline phases, and the structural change in the nanocrystalline phase was caused by increasing the duration of heat treatment for crystallization. From the results, it was evident that this behavior affected the ratio of $\mathrm{V}^{5+}$ to $\mathrm{V}^{4+}$.

We presumed that the changes in the electrical conduction and catalytic properties were induced by the heat treatment. The causes behind the characteristic changes and the action mechanism were investigated through qualitative and quantitative analysis of X-ray diffraction (XRD) patterns, Xray photoelectron spectroscopy (XPS), and Fourier transform infrared (FTIR) spectroscopy. We examined the quantitative physical properties such as density and molar volume to verify the predicted action mechanism.

\section{Materials and Methods}

2.1. Glass Preparation and Nanocrystallization. $75 \mathrm{~V}_{2} \mathrm{O}_{5}$ $15 \mathrm{~B}_{2} \mathrm{O}_{3}-10 \mathrm{P}_{2} \mathrm{O}_{5}$ glass samples were prepared using reagentgrade $\mathrm{NH}_{4} \mathrm{H}_{2} \mathrm{PO}_{4}, \mathrm{~V}_{2} \mathrm{O}_{5}$, and $\mathrm{B}_{2} \mathrm{O}_{3}$ (Junsei Chemical Co., Ltd., Japan). The constituents were mixed in an alumina mortar for $10 \mathrm{~min}$ to produce multiple batches. Well-mixed batches were first melted in an alumina crucible using an electrical furnace at $200^{\circ} \mathrm{C}$ for $1 \mathrm{~h}$ (first calcination), subsequently at $500^{\circ} \mathrm{C}$ for $2 \mathrm{~h}$ (second calcination), and finally at $800^{\circ} \mathrm{C}$ for $2 \mathrm{~h}$. The resultant melt was quenched between two stainless steel plates.

The as-prepared sample was crushed in an automatic grinding mixer and sieved through a 325 mesh. This powder (particle size below $44 \mu \mathrm{m}$ ) was used for differential scanning calorimetry (DSC), XRD, XPS, FTIR, and thermogravimetric analysis (TGA) measurements.

DSC was performed on the samples using an SDT (SDT Q600, TA instrument, USA) to determine both the glass transition $\left(T_{g}\right)$ and the crystallization $\left(T_{c}\right)$ temperatures, as shown in Figure 1(a). The glasses were annealed in a graphite mold above $T_{g}$ for $4 \mathrm{~h}$ and heat-treated at $T_{c}$ for 1,3 , or $5 \mathrm{~h}$. Detailed heating profiles are provided in Figure 1(b).

The glass samples used for the experiments (electrical conductivity, density, and molar volume) were rectangular parallelepipeds and their surfaces were polished using $\mathrm{SiC}$ paper (\#220-1000).

2.2. Measurement. XRD measurements were taken in a Rigaku Co. RINT 2000 using $\mathrm{Cu}-\mathrm{K} \alpha$ radiation in the $10-$ $80^{\circ} 2 \theta$ range with a step size of $0.02^{\circ}$. The existence of the nanocrystal phase was confirmed using the resultant XRD patterns. The nanocrystal phases were observed by field emission scanning electron microscopy (FE-SEM, Carl Zeiss, Supra 25).

We investigated the structural changes using FTIR spectroscopy. Powdered samples mixed with $\mathrm{KBr}$ (mixing ratio $1: 1200)$ were prepared and dried at $100^{\circ} \mathrm{C}$ in a desiccator to form pellets. A Spectrum GX (Perkin Elmer Co, USA) spectrometer was used to perform FTIR. Room temperature IR spectra were recorded from 400 to $1400 \mathrm{~cm}^{-1}$ (injection number of times: 20; resolving power: $2 \mathrm{~cm}^{-1}$ ).

XPS was used to analyze the change in the valency of vanadium cations in the glass. XPS measurements were taken using the ESCALAB250 XPS system and the Theta Probe XPS system using monochromatic Al-K $\alpha(h \nu=1486.6 \mathrm{eV})$ radiation. The analysis area was $400 \mu \mathrm{m}$ and the data was compensated using Cls $(284.6 \mathrm{eV})$ as the reference.

The catalytic properties and electrical conductivity are the main characteristics considered in this study. First, in order to measure the electrical conductivity of each specimen, the carrier density was measured at room temperature using a Hall-effect measurement system (HMS-3000 Hall Measurement System, ECOPIA). Furthermore, to examine the catalytic effect of the glass samples applied to the oxidation of fatty acids (linoleic acid and stearic acid) and carbon, we performed TGA on two samples obtained by mixing $20 \mathrm{mg}$ of 

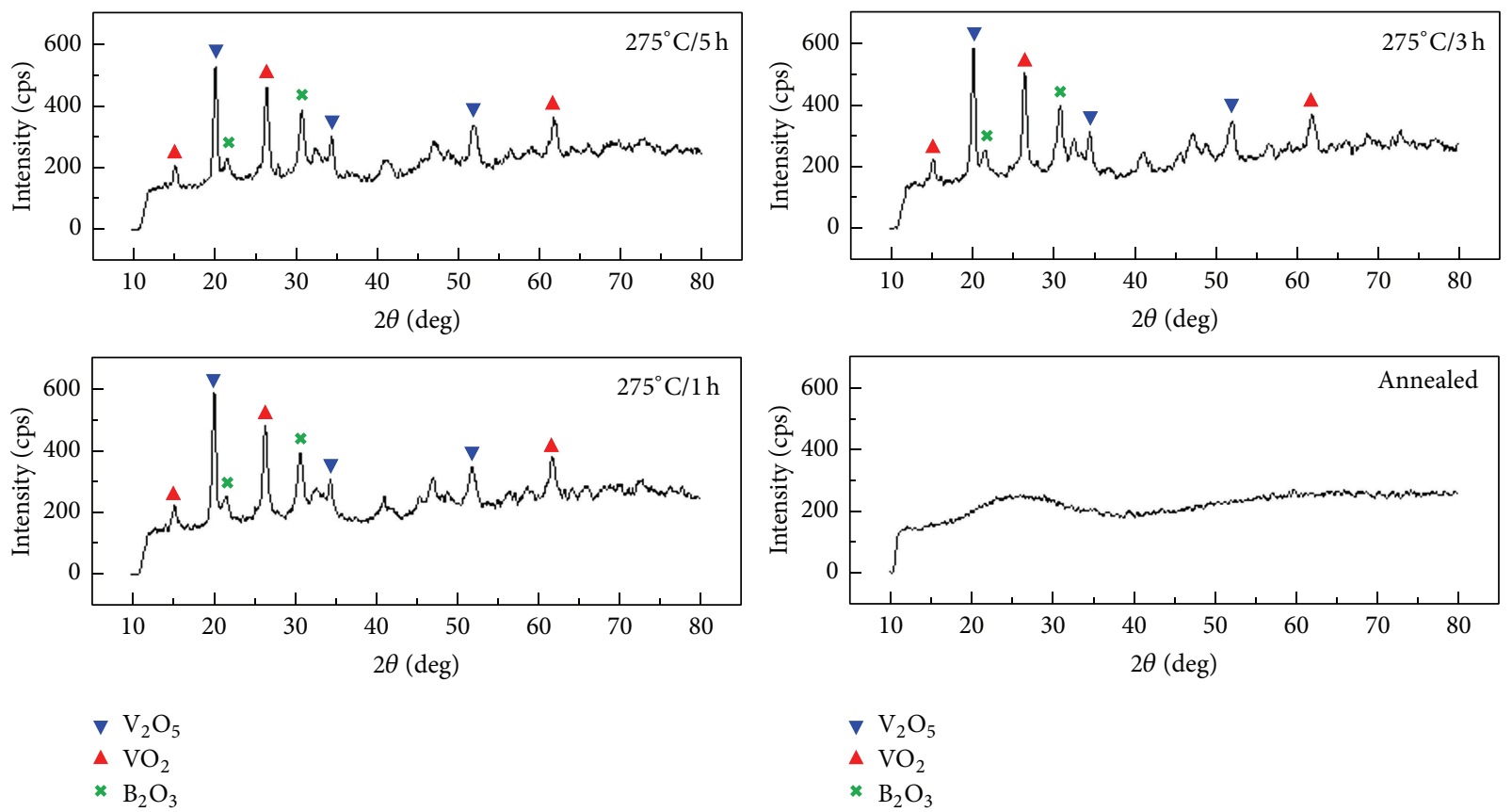

FIGURE 2: XRD patterns of $75 \mathrm{~V}_{2} \mathrm{O}_{5}-15 \mathrm{~B}_{2} \mathrm{O}_{3}-10 \mathrm{P}_{2} \mathrm{O}_{5}$ glasses heat-treated at $275^{\circ} \mathrm{C}$.

fatty acid with $20 \mathrm{mg}$ of glass powder and gas chromatography with a mass spectrometer (GC-MSD) on a sample obtained by mixing $2 \mathrm{mg}$ of carbon with $8 \mathrm{mg}$ of glass powder. TGA measurements were obtained between room temperature and $600^{\circ} \mathrm{C}$ at a heating rate of $10^{\circ} \mathrm{C} / \mathrm{min}$ in an atmosphere of 5 vol\% using a simultaneous TGA/DSC (Q600, TA Instruments, Inc.). The fatty acids used in the experiments are reagent-grade stearic acid (95\%) and technical grade linoleic acid (60-74\%, GC), both from Sigma-Aldrich Co. GC-MSD measurements were obtained between room temperature and $450^{\circ} \mathrm{C}$ at a heating rate of $10^{\circ} \mathrm{C} \cdot \mathrm{min}^{-1}$ in an atmosphere of $\mathrm{He}$ and $\mathrm{O}_{2}$ using a 5975MSD-6890N GC (Agilent). He gas was used at a flow rate of $20 \mathrm{~mL} / \mathrm{min}$ and $\mathrm{O}_{2}$ gas was used at a flow rate of $2 \mathrm{~mL} / \mathrm{min}$.

Changes in quantitative properties due to structural changes were confirmed using the molar volume and density measurements. The densities of the glass samples were measured using the Archimedes method using a GH-200 (AND Co, Korea), and the molar volume $\left(V_{M}\right)$ was calculated from the measured density using $V_{M} \equiv \bar{M} / \rho$ [9], where $\bar{M}$ is the average molar weight of glass.

\section{Results and Discussion}

3.1. Analysis of Nanocrystal Phases. Figure 2 shows the diffraction patterns of all the samples studied, which were annealed for $4 \mathrm{~h}$ and heat-treated at $275^{\circ} \mathrm{C}$ for different durations $(1,3$, and $5 \mathrm{~h}) . \mathrm{A} \mathrm{V}_{2} \mathrm{O}_{5}$ phase $\left(\mathrm{V}^{5+} / \mathrm{JCPDS}-\mathrm{PDF}\right.$ 85-0601) coexisting with the $\mathrm{VO}_{2}\left(\mathrm{~V}^{4+} / \mathrm{JCPDS}-\mathrm{PDF} 73-0514\right)$ and $\mathrm{B}_{2} \mathrm{O}_{3}\left(\mathrm{BO}_{4} / \mathrm{JCPDS}-\mathrm{PDF} 760781\right)$ phases was detected in samples heat-treated at $275^{\circ} \mathrm{C}$. As the holding time at $275^{\circ} \mathrm{C}$ increased, the relative amounts of $\mathrm{VO}_{2}$ and $\mathrm{B}_{2} \mathrm{O}_{3}$ increased while the relative amount of $\mathrm{V}_{2} \mathrm{O}_{5}$ decreased; that is, $\mathrm{VO}_{2}$ and $\mathrm{BO}_{4}$ structures are strengthened by nanocrystallizing the $75 \mathrm{~V}_{2} \mathrm{O}_{5}-15 \mathrm{~B}_{2} \mathrm{O}_{3}-10 \mathrm{P}_{2} \mathrm{O}_{5}$ ternary glass. Combining this fact with the results of the FTIR analysis (Section 3.3), which explains the structural change of $\mathrm{BO}_{3}$ to $\mathrm{BO}_{4}$, the nanocrystallization of the $\mathrm{VO}_{2}$ phase occurred and this nanocrystal was strengthened while the $\mathrm{V}_{2} \mathrm{O}_{5}$ phase was comparatively weakened as the heat treatment at $275^{\circ} \mathrm{C}$ progressed. This suggested that a structural change, indicated by the reaction $\mathrm{BO}_{3}+\mathrm{VO}_{5}\left(\mathrm{~V}_{2} \mathrm{O}_{5}\right) \rightarrow \mathrm{BO}_{4}+\mathrm{VO}_{4}\left(\mathrm{VO}_{2}\right)$, was induced by the heat treatment at $275^{\circ} \mathrm{C}$. This structural change is a factor that affects the electrical conduction and catalytic properties of the vanadate glass.

Figure 3 shows the SEM images of all samples studied, which were annealed for $4 \mathrm{~h}$ and heat-treated at $275^{\circ} \mathrm{C}$ for different durations (1, 3, and $5 \mathrm{~h}$ ). Nanocrystallines of $\mathrm{VO}_{2}$ phase were detected in samples heat-treated at $275^{\circ} \mathrm{C}$. As the holding time at $275^{\circ} \mathrm{C}$ increased, the amounts of nanocrystalline increased.

3.2. XPS Spectroscopy. To quantitatively determine the change in the vanadium ion valency, we performed an XPS analysis on each glass sample. The V 2 p spin orbit doublet spectra of $75 \mathrm{~V}_{2} \mathrm{O}_{5}-15 \mathrm{~B}_{2} \mathrm{O}_{3}-10 \mathrm{P}_{2} \mathrm{O}_{5}$ glasses are shown in Figure 4 . The XPS analysis was performed while maintaining the same X-ray energy, X-ray-to-sample positioning, and sampling time for all the four samples in accordance with the nanocrystallization conditions. V 2p peaks appeared asymmetrically in each sample, indicating that the vanadium ions are present in more than one oxidation state [10]. According to previous studies on vanadium phosphate glasses, core level spectra of $\mathrm{V}^{5+}$ appear at a binding energy (BE) of $517.3 \mathrm{eV}$, while that of $\mathrm{V}^{4+}$ appears at $516.0 \mathrm{eV}$ [11-14]. Therefore, when the $\mathrm{V} 2 \mathrm{p}_{3 / 2}$ core level spectrum is fitted to the $\mathrm{BE}$ 


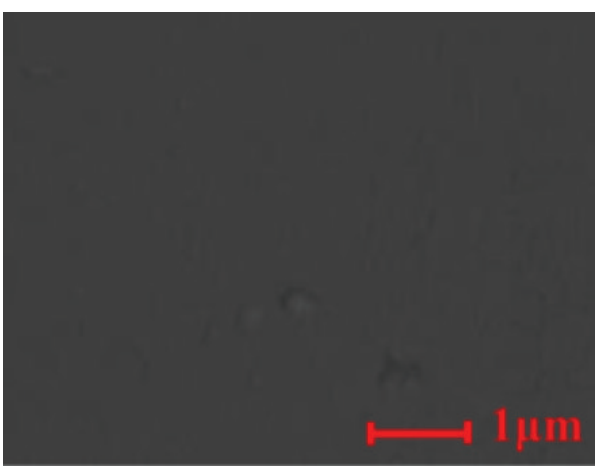

(a)

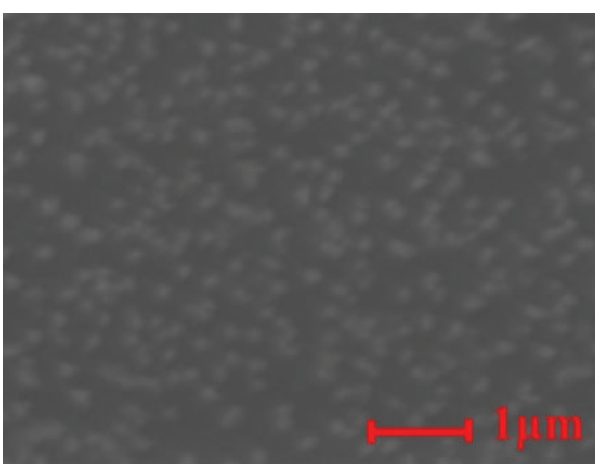

(c)

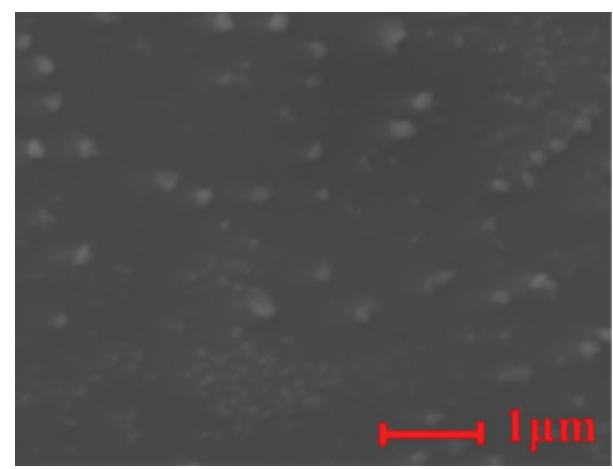

(b)

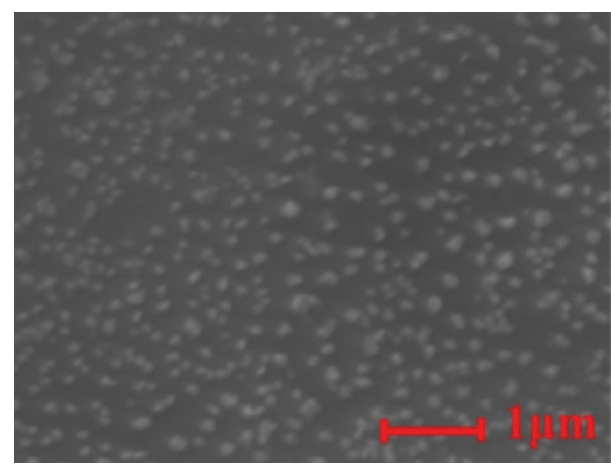

(d)

Figure 3: SEM images of $75 \mathrm{~V}_{2} \mathrm{O}_{5}-15 \mathrm{~B}_{2} \mathrm{O}_{3}-10 \mathrm{P}_{2} \mathrm{O}_{5}$ glasses (a) annealed at $225^{\circ} \mathrm{C}$ and heated for crystallization at $275^{\circ} \mathrm{C}$ for (b) 1 , (c) 3 , and (d) $5 \mathrm{~h}$.

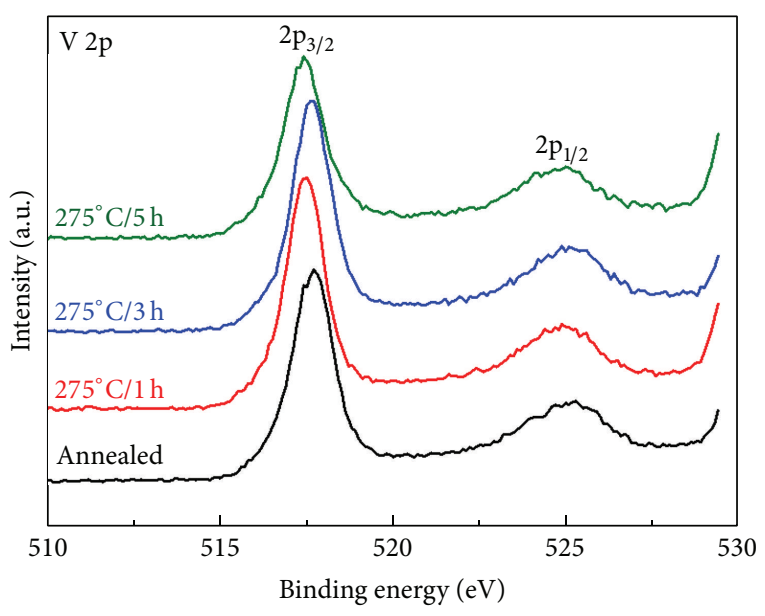

Figure 4: Core level V 2p spectra for the $75 \mathrm{~V}_{2} \mathrm{O}_{5}-15 \mathrm{~B}_{2} \mathrm{O}_{3}-10 \mathrm{P}_{2} \mathrm{O}_{5}$ glasses heat-treated at $275^{\circ} \mathrm{C}$.

of $517.3 \mathrm{eV}$ of the $\mathrm{V}^{5+}$ ions and $516.1 \mathrm{eV}$ of the $\mathrm{V}^{4+}$ ions, quantitative analysis for the concentration of $\mathrm{V}^{5+}$ and $\mathrm{V}^{4+}$ became possible [15]. The $\mathrm{V}^{5+}$ and $\mathrm{V}^{4+}$ peaks of the $75 \mathrm{~V}_{2} \mathrm{O}_{5^{-}}$ $15 \mathrm{~B}_{2} \mathrm{O}_{3}-10 \mathrm{P}_{2} \mathrm{O}_{5}$ glass, obtained from the vanadium GaussianLorentzian peaks, fitted using the least squares method, are shown in Figure 5. The relative content ratios of $\mathrm{V}^{5+} / \mathrm{V}_{\text {total }}$ and $\mathrm{V}^{4+} / \mathrm{V}_{\text {total }}$ obtained using this fit are shown in Table 1.
It was found that the content of the $\mathrm{V}^{5+}$ in glass was reduced and $\mathrm{V}^{4+}$ was increased by nanocrystallizing $75 \mathrm{~V}_{2} \mathrm{O}_{5}$ $15 \mathrm{~B}_{2} \mathrm{O}_{3}-10 \mathrm{P}_{2} \mathrm{O}_{5}$ glass and increasing the heat treatment time for crystallization. This means that the $\mathrm{V}^{5+}$ to $\mathrm{V}^{4+}$ reduction reaction occurs during nanocrystallization at $275^{\circ} \mathrm{C}$ and increments in the heat treatment duration. This behavior is in agreement with the trends in the catalytic properties (Section 3.5) and electrical conductivity (Section 3.4). We have confirmed that the changes in concentration and state of vanadium ions due to nanocrystallization contribute directly to the characteristic change in the $75 \mathrm{~V}_{2} \mathrm{O}_{5}-15 \mathrm{~B}_{2} \mathrm{O}_{3}-10 \mathrm{P}_{2} \mathrm{O}_{5}$ glass.

3.3. FTIR Spectroscopy. XPS analysis was performed to verify the changes in the concentration and state of the vanadium ions in the glass due to nanocrystallization. The structural changes were expected to induce a change in the concentrations of $\mathrm{V}^{5+}$ and $\mathrm{V}^{4+}$. Results of FTIR spectroscopy provided a direct evidence for the $\mathrm{BO}_{4}$ restructuring observed in the $\mathrm{XRD}$ analysis. The infrared spectra (at $400-2000 \mathrm{~cm}^{-1}$ ) of the $75 \mathrm{~V}_{2} \mathrm{O}_{5}-15 \mathrm{~B}_{2} \mathrm{O}_{3}-10 \mathrm{P}_{2} \mathrm{O}_{5}$ glass annealed for $4 \mathrm{~h}$ and heattreated at $275^{\circ} \mathrm{C}$ for different durations $(1,3$, and $5 \mathrm{~h}$ ) are shown in Figure 6 . The vibration modes of the borate network were found to be active mainly in three infrared regions, as previously reported $[16,17]$. The group of bands located at $1200-1600 \mathrm{~cm}^{-1}$ is attributed to the B-O bonds in the trigonal 


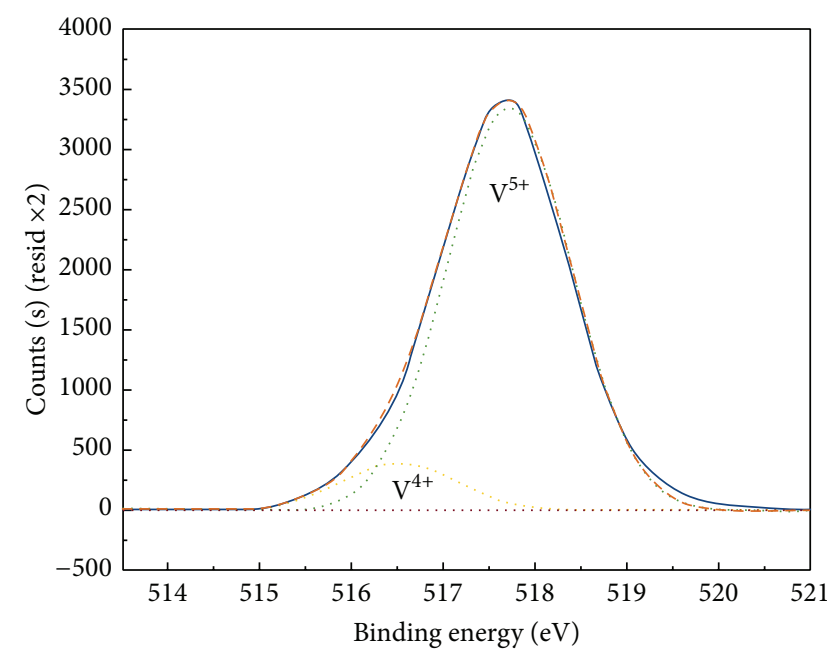

(a)

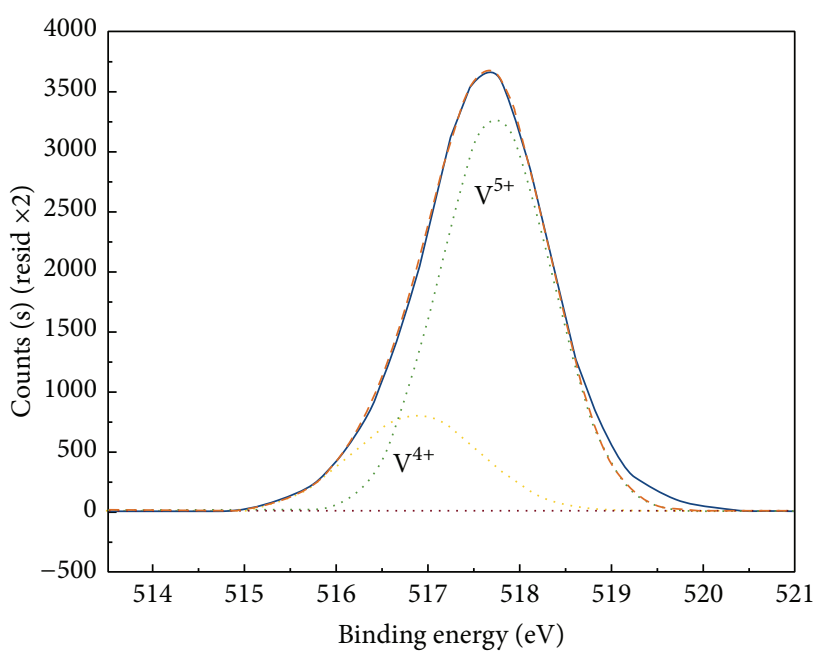

_ Experimental

- . - Fit sum

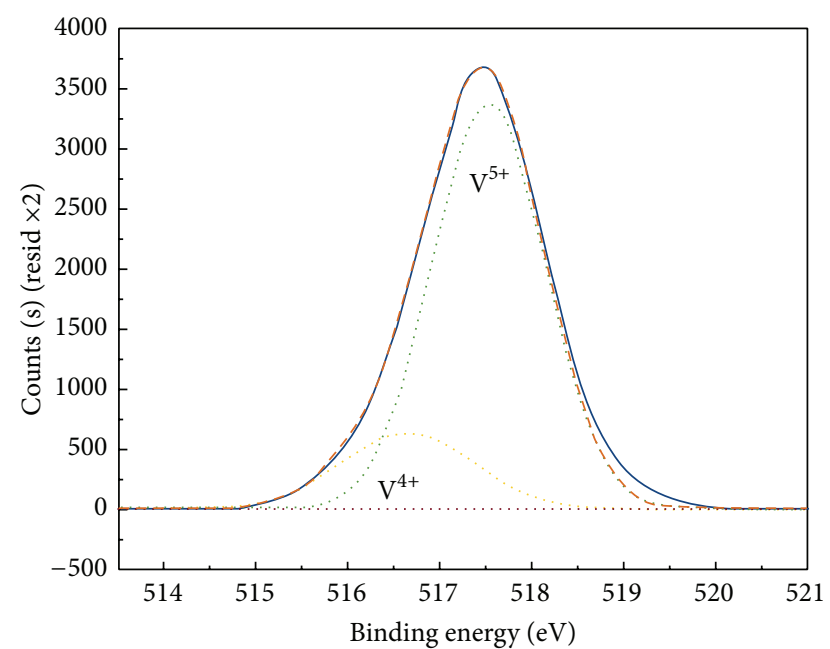

(b)

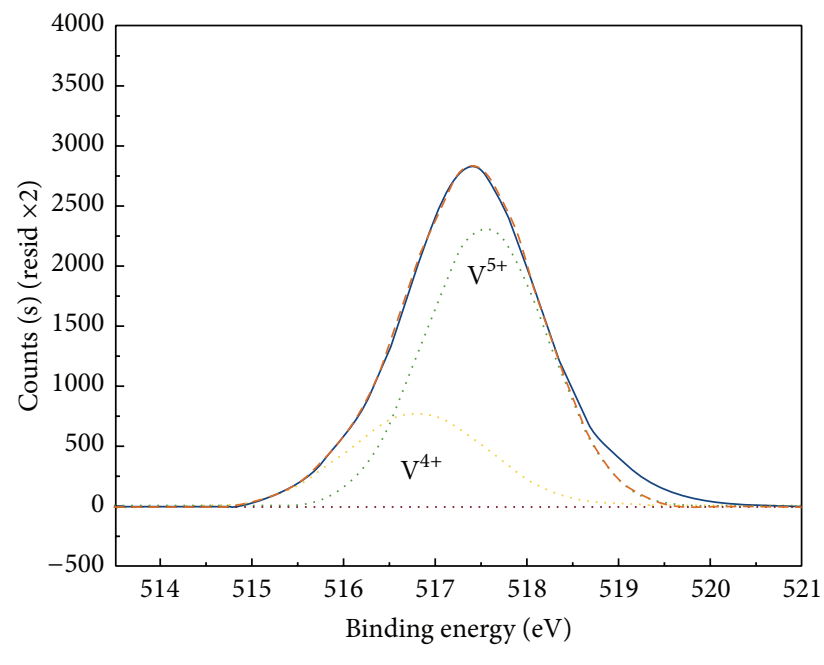

- Experimental

- - - Fit sum

(c)

(d)

FIgURE 5: $\mathrm{V} 2 \mathrm{p}_{3 / 2}$ core level spectra fitted with a single peak of $\mathrm{V}^{5+}$ and $\mathrm{V}^{4+}$ for glasses (a) annealed at $225^{\circ} \mathrm{C}$ and heated for crystallization at $275^{\circ} \mathrm{C}$ for (b) 1 , (c) 3 , and (d) $5 \mathrm{~h}$.

TABLE 1: Peak positions, areas, and relative concentrations of $\mathrm{V}^{4+}$ and $\mathrm{V}^{5+}$ resulting from the curve fittings of the $\mathrm{V} 2 \mathrm{p}$ spectra of the $75 \mathrm{~V}_{2} \mathrm{O}_{5}$ $15 \mathrm{~B}_{2} \mathrm{O}_{3}-10 \mathrm{P}_{2} \mathrm{O}_{5}$ glasses heat-treated at $275^{\circ} \mathrm{C}$.

\begin{tabular}{|c|c|c|c|c|c|c|}
\hline Heating process & Peak BE & Height counts & FWHM $(\mathrm{eV})$ & Area & {$\left[\mathrm{V}^{5+}\right] /\left[\mathrm{V}_{\text {total }}\right]$} & {$\left[\mathrm{V}^{4+}\right] /\left[\mathrm{V}_{\text {total }}\right]$} \\
\hline \multirow{2}{*}{ Annealed } & 517.71 & 3353.98 & 1.60 & 5705.38 & \multirow{2}{*}{0.9033} & \multirow{2}{*}{0.0967} \\
\hline & 516.52 & 390.71 & 1.47 & 611.07 & & \\
\hline \multirow{2}{*}{$275^{\circ} \mathrm{C} / 1 \mathrm{~h}$} & 517.53 & 3374.83 & 1.45 & 5214.94 & \multirow{2}{*}{0.8202} & \multirow{2}{*}{0.1798} \\
\hline & 516.64 & 632.89 & 1.70 & 1143.24 & & \\
\hline \multirow{2}{*}{$275^{\circ} \mathrm{C} / 3 \mathrm{~h}$} & 517.74 & 3275.23 & 1.45 & 5052.32 & \multirow{2}{*}{0.7823} & \multirow{2}{*}{0.2177} \\
\hline & 516.88 & 802.80 & 1.65 & 1406.09 & & \\
\hline \multirow{2}{*}{$275^{\circ} \mathrm{C} / 5 \mathrm{~h}$} & 517.54 & 2328.67 & 1.58 & 3919.33 & \multirow{2}{*}{0.7230} & \multirow{2}{*}{0.2770} \\
\hline & 516.80 & 779.33 & 1.81 & 1501.61 & & \\
\hline
\end{tabular}




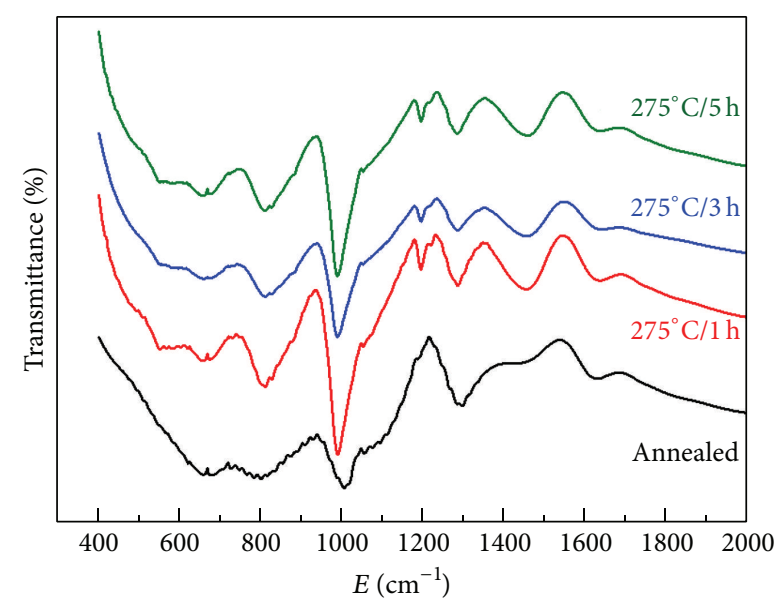

FIgURE 6: Infrared spectra of $75 \mathrm{~V}_{2} \mathrm{O}_{5}-15 \mathrm{~B}_{2} \mathrm{O}_{3}-10 \mathrm{P}_{2} \mathrm{O}_{5}$ glass heattreated at $275^{\circ} \mathrm{C}$.

$\mathrm{BO}_{3}$ units. The second group of bands, located at $800-$ $1200 \mathrm{~cm}^{-1}$, could be ascribed to the $\mathrm{B}-\mathrm{O}$ bond stretching in the tetrahedral $\mathrm{BO}_{4}$ units. A third group of absorption bands was observed at around $600 \mathrm{~cm}^{-1}$, which can be attributed to the bending of O-B-O linkages in the borate network $[18,19]$.

The absence of a peak at $809 \mathrm{~cm}^{-1}$ indicates that no boroxol ring was formed [20], which suggests that the glass system under investigation consists of randomly connected $\mathrm{BO}_{3}$ and $\mathrm{BO}_{4}$ groups. The absorption peaks at 1195 and $1465 \mathrm{~cm}^{-1}$ are related to the fundamental asymmetrical stretching vibration of the $\mathrm{B}-\mathrm{O}$ bond in the trigonal $\mathrm{BO}_{3}$ units [21, 22]. Mitigation of the slope of the absorption band indicated that $\mathrm{B}-\mathrm{O}$ bond stretching in the trigonal $\mathrm{BO}_{3}$ units occurred during heat treatment at $275^{\circ} \mathrm{C}$. In addition, the absorption peak intensity at $1468 \mathrm{~cm}^{-1}\left(\mathrm{BO}_{3}\right.$ structure $)$ shifted to lower wave numbers $\left(1468-1430 \mathrm{~cm}^{-1}\right)$ as the heat treatment was significantly reduced. The stretching vibration of the $\mathrm{B}-\mathrm{O}$ bond in the tetrahedral $\mathrm{BO}_{4}$ units appeared at $1050-900 \mathrm{~cm}^{-1}$. The absorption peak at $1019 \mathrm{~cm}^{-1}$, attributed to the $\mathrm{B}-\mathrm{O}$ bond stretching vibration in the tetrahedral $\mathrm{BO}_{4}$ units, shifted to higher wave numbers $\left(1019-1020 \mathrm{~cm}^{-1}\right)$ upon heat treatment at $275^{\circ} \mathrm{C}[17,23]$.

From the FTIR analysis, shift of the vibrational band indicated that nanocrystallization at $275^{\circ} \mathrm{C}$ with increasing durations of heat treatment strengthened the $\mathrm{BO}_{4}$ unit structure and weakened the $\mathrm{BO}_{3}$ unit structure. This fact, coupled with the $\mathrm{XRD}$ analysis results, allowed us to examine the $\mathrm{BO}_{3}+\mathrm{VO}_{5}\left(\mathrm{~V}_{2} \mathrm{O}_{5}\right) \rightarrow \mathrm{BO}_{4}+\mathrm{VO}_{4}\left(\mathrm{VO}_{2}\right)$ structural change that occurred in the glass. This structural change affects the electrical conduction and catalytic properties of the vanadate glass.

3.4. Electrical Conductivity. The changes in the electrical conductivity of the heat-treated specimens are shown in Table 2. Electrical conductivity was increased by heat-treating the samples at $275^{\circ} \mathrm{C}$ and increasing the duration of the heat treatment.

The resulting conductivity value of $1.42003 \times 10^{-7} \Omega^{-1}$ obtained by heat treatment at $275^{\circ} \mathrm{C}$ for $1 \mathrm{~h}$ was approximately
TABLE 2: Electrical conductivity of $75 \mathrm{~V}_{2} \mathrm{O}_{5}-15 \mathrm{~B}_{2} \mathrm{O}_{3}-10 \mathrm{P}_{2} \mathrm{O}_{5}$ glasses heat-treated at $275^{\circ} \mathrm{C}$.

\begin{tabular}{lcc}
\hline Heating process & Electric resistance & Electrical conductivity \\
\hline Annealed & 35857142.86 & $0.278884 E-07$ \\
$275^{\circ} \mathrm{C} / 1 \mathrm{~h}$ & 7042105.263 & $1.42003 E-07$ \\
$275^{\circ} \mathrm{C} / 3 \mathrm{~h}$ & 1765000 & $5.66572 E-07$ \\
$275^{\circ} \mathrm{C} / 5 \mathrm{~h}$ & 1330769.231 & $7.51445 E-07$ \\
\hline
\end{tabular}

5.1 times greater than the conductivity of the annealed glass. Furthermore, the resulting value of $7.51445 \times 10^{-7} \Omega^{-1}$ obtained by heat treatment at $275^{\circ} \mathrm{C}$ for $5 \mathrm{~h}$ was approximately 26.9 times greater than the conductivity of annealed glass.

Combining result of the electrical conductivity with those of the XRD and XPS analyses, it was hypothesized that the change in the electrical properties was because of the changes in the $\mathrm{VO}_{5}$ and $\mathrm{VO}_{4}$ structures caused by the change in the coordination number, which was due to the nanocrystallization. Electrical conductivity of this glass system is related to the metal ion value ratio $\mathrm{C}$, which for vanadium-containing oxide glasses is defined as $=\left[\mathrm{V}^{4+}\right] /\left[\mathrm{V}^{4+}\right]\left[\mathrm{V}^{5+}\right]$. According to Morinaga and Fujino [24], the electrical conductivity of vanadate glasses increases as $\mathrm{C}$ approaches 0.5 . Heat-treating the $75 \mathrm{~V}_{2} \mathrm{O}_{5}-15 \mathrm{~B}_{2} \mathrm{O}_{3}-10 \mathrm{P}_{2} \mathrm{O}_{5}$ glass at $275^{\circ} \mathrm{C}$ nanocrystallizes and strengthens the $\mathrm{VO}_{2}$ phase while reducing the $\mathrm{V}_{2} \mathrm{O}_{5}$ phase. This indicates that the $\mathrm{V}^{5+}$ ions changed to $\mathrm{V}^{4+}$ as values of $\mathrm{C}$ approached 0.5 . From these inferences, it can be predicted that this behavior leads to an increase in the electrical conductivity and that increasing the conduction path length, number of electronic transfer ports, and the $\mathrm{VO}_{2}$ nanocrystalline phase contribute to this increased conductivity.

3.5. Catalytic Property. TGA results of two samples containing $20 \mathrm{mg}$ of glass powder nanocrystallized at each heat treatment condition mixed with $20 \mathrm{mg}$ of stearic acid or linoleic acid are shown in Figure 7 and Table 3. Linoleic acid $\left(\mathrm{CH}_{3}\left(\mathrm{CH}_{2}\right)_{4} \mathrm{CH}=\mathrm{CHCH}_{2} \mathrm{CH}=\mathrm{CH}\left(\mathrm{CH}_{2}\right)_{7} \mathrm{CO}_{2} \mathrm{H}\right)$ is a typical unsaturated fatty acid with two double bonds, and stearic acid $\left(\mathrm{CH}_{3}\left(\mathrm{CH}_{2}\right)_{16} \mathrm{COOH}\right)$ is a typical saturated higher fatty acid with a carbon number of 18 . Weight loss occurs when each fatty acid was partially converted to $\mathrm{CO}_{2}$ gas by an oxidation reaction.

The finish temperature of weight loss, which is the temperature at which the oxidation reaction of linoleic acid and stearic acid is complete, associated with the conversion of the acid to $\mathrm{CO}_{2}$ gas caused by crystallization due to $1 \mathrm{~h}$ heat treatment at $275^{\circ} \mathrm{C}$, shifted to lower temperatures ( 356.05 to $324.15^{\circ} \mathrm{C}$ for linoleic acid and 378.67 to $341.75^{\circ} \mathrm{C}$ for stearic acid). Subsequently, the finish temperature of weight loss increases gradually by increasing the heat treatment duration. The finish temperature of samples heat-treated for $5 \mathrm{~h}$ was $340.96^{\circ} \mathrm{C}$ and $362.16^{\circ} \mathrm{C}$ for linoleic and stearic acids, respectively.

GC-MSD results of a sample containing $2 \mathrm{mg}$ glass powder nanocrystallized at each heat treatment condition mixed with $8 \mathrm{mg}$ of carbon are shown in Figure 8. Carbon 


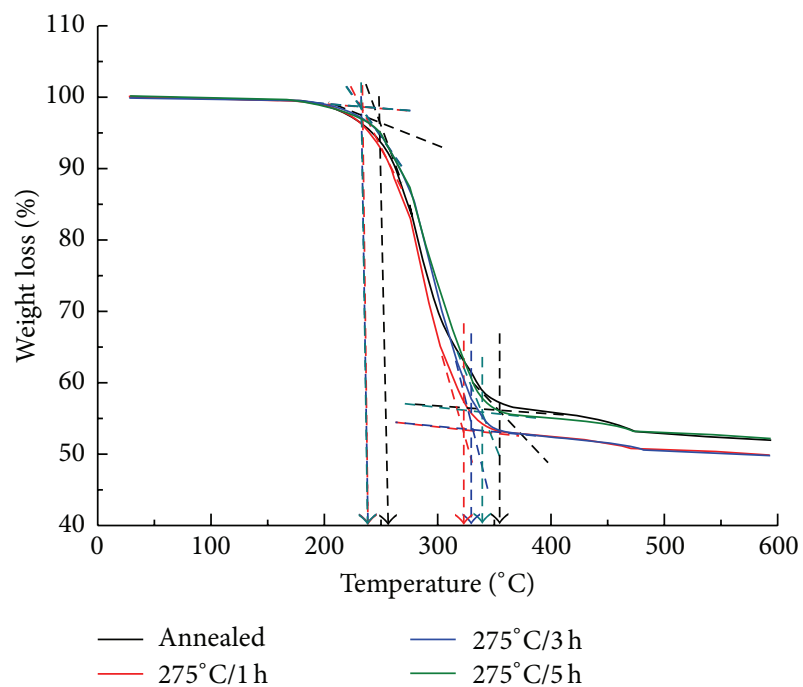

(a)

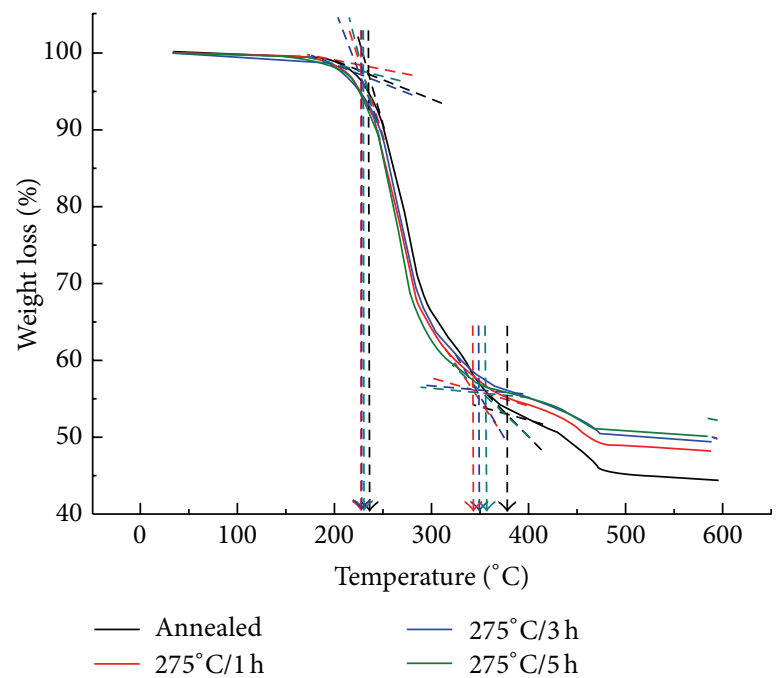

(b)

FIgURE 7: Weight loss of (a) linoleic and (b) stearic acids with $75 \mathrm{~V}_{2} \mathrm{O}_{5}-15 \mathrm{~B}_{2} \mathrm{O}_{3}-10 \mathrm{P}_{2} \mathrm{O}_{5}$ glass heat-treated at $275^{\circ} \mathrm{C}$.

TABLE 3: Weight loss of linoleic and stearic acids with $75 \mathrm{~V}_{2} \mathrm{O}_{5}-15 \mathrm{~B}_{2} \mathrm{O}_{3}-10 \mathrm{P}_{2} \mathrm{O}_{5}$ glass heat-treated at $275^{\circ} \mathrm{C}$.

\begin{tabular}{lcccc}
\hline \multirow{2}{*}{ Heating process } & \multicolumn{2}{c}{ Linoleic acid } & \multicolumn{2}{c}{ Stearic acid } \\
& $\begin{array}{c}\text { Start temp. of weight } \\
\text { loss }\end{array}$ & $\begin{array}{c}\text { Finish temp. of weight } \\
\text { loss }\end{array}$ & $\begin{array}{c}\text { Start temp. of weight } \\
\text { loss }\end{array}$ & $\begin{array}{c}\text { Finish temp. of weight } \\
\text { loss }\end{array}$ \\
\hline Annealed & 254.19 & 356.05 & 235.56 & 378.67 \\
$275^{\circ} \mathrm{C} / 1 \mathrm{~h}$ & 245.24 & 324.15 & 233.23 & 341.75 \\
$275^{\circ} \mathrm{C} / 3 \mathrm{~h}$ & 244.02 & 330.92 & 233.55 & 350.02 \\
$275^{\circ} \mathrm{C} / 5 \mathrm{~h}$ & 244.23 & 340.96 & 233.62 & 362.16 \\
\hline
\end{tabular}

converted into $\mathrm{CO}_{2}$ gas by an oxidation reaction, and hence, the desorption intensity of $\mathrm{CO}_{2}$ gas increases.

The sudden increase point of the desorption intensity, which is the temperature at which the oxidation reaction of carbon is complete, associated with the conversion of the carbon to $\mathrm{CO}_{2}$ gas because of nanocrystallization after $1 \mathrm{~h}$ heat treatment at $275^{\circ} \mathrm{C}$, shifted from $395.13^{\circ} \mathrm{C}$ to $281.25^{\circ} \mathrm{C}$ (Table 4). Thereafter, the sudden increase point of the desorption intensity gradually decreased by increasing the heat treatment duration. The sudden increase point after $5 \mathrm{~h}$ of heat treatment was $387.98^{\circ} \mathrm{C}$.

Prior research results have shown that the $\mathrm{V}^{5+}$ to $\mathrm{V}^{4+}$ reduction reaction causes a catalytic effect in the oxidation reaction of reactants (linoleic and stearic acids and carbon), and the XRD, XPS, and FTIR analyses of the structural changes due to the glass nanocrystallization lead to the following conclusion. We hypothesize that, by nanocrystallizing a given composition of glass at $275^{\circ} \mathrm{C}$, nanocrystal phases are produced and the glass structure is changed to a relatively more closed structure (see Section 3.6 ). It was determined that the tunneling effect, which is the electron transfer mechanism in the vanadate glass structure, becomes more active. However, as the heat treatment time became progressively longer, the catalytic effect diminished in strength. By increasing the heat treatment time, the relative amount
TABLE 4: Sudden increase point of the desorption intensity of $\mathrm{CO}_{2}$ gas from carbon with $75 \mathrm{~V}_{2} \mathrm{O}_{5}-15 \mathrm{~B}_{2} \mathrm{O}_{3}-10 \mathrm{P}_{2} \mathrm{O}_{5}$ glass heat-treated at $275^{\circ} \mathrm{C}$.

\begin{tabular}{lc}
\hline Heating process & Sudden increase point of the desorption $\left({ }^{\circ} \mathrm{C}\right)$ \\
\hline Annealed & 395.15 \\
$275^{\circ} \mathrm{C} / 1 \mathrm{~h}$ & 281.25 \\
$275^{\circ} \mathrm{C} / 3 \mathrm{~h}$ & 376.24 \\
$275^{\circ} \mathrm{C} / 5 \mathrm{~h}$ & 388.98 \\
\hline
\end{tabular}

of the $\mathrm{VO}_{2}$ phase increased while that of $\mathrm{VO}_{5}$ decreased, changing the vanadium ion valency from $\mathrm{V}^{5+}$ to $\mathrm{V}^{4+}$. Thus, the $\mathrm{V}^{5+}$ activity and the reduction reaction of $\mathrm{V}^{4+}$ decrease gradually, weakening the catalytic property. Therefore, glass nanocrystallization due to heat treatment creates a denser structure than annealed glass. This causes the $\mathrm{V}^{5+}$ to $\mathrm{V}^{4+}$ reduction reaction and catalytic action of the oxidation of fatty acid to become active. On the other hand, as the heat treatment time increased, the reduction reaction decreased, indicating that the catalytic effects declined gradually.

3.6. Other Properties. We examined the density and molar volume to obtain indirect evidence of the structural changes and the associated catalytic properties described above. 


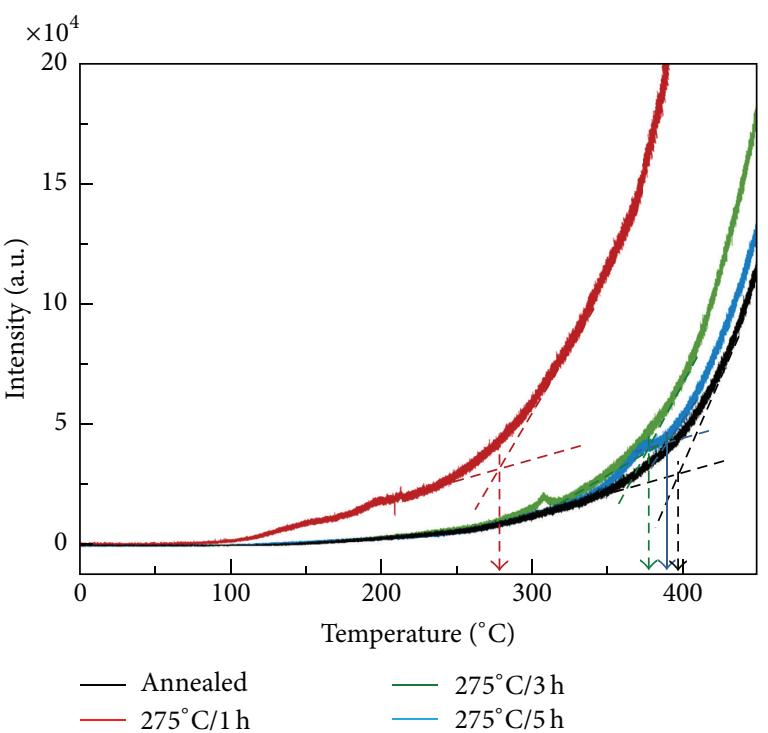

FIGURE 8: Desorption intensity of $\mathrm{CO}_{2}$ gas from carbon conversion with $75 \mathrm{~V}_{2} \mathrm{O}_{5}-15 \mathrm{~B}_{2} \mathrm{O}_{3}-10 \mathrm{P}_{2} \mathrm{O}_{5}$ glass heat-treated at $275^{\circ} \mathrm{C}$.

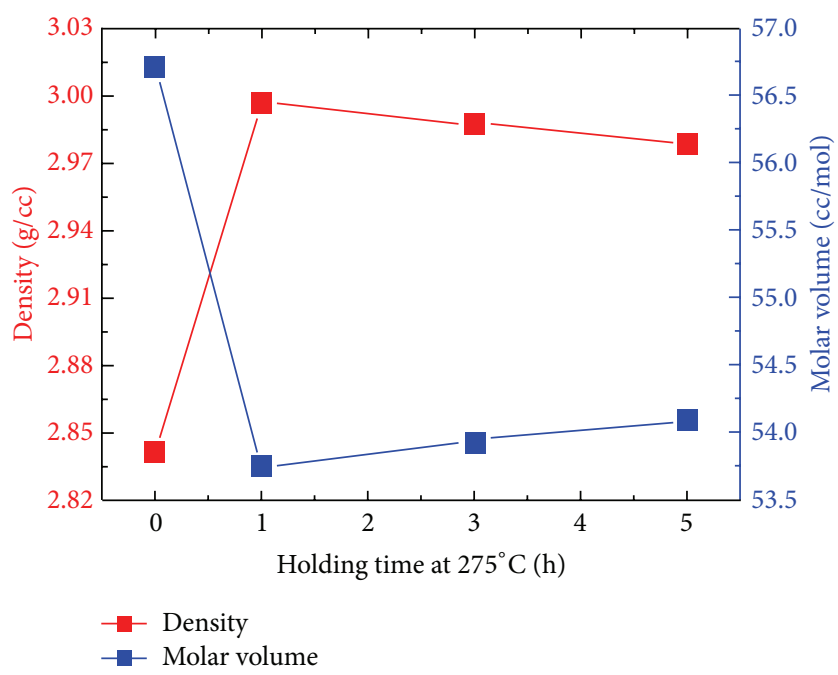

FIgURE 9: Density and molar volume of $75 \mathrm{~V}_{2} \mathrm{O}_{5}-15 \mathrm{~B}_{2} \mathrm{O}_{3}-15 \mathrm{P}_{2} \mathrm{O}_{5}$ glasses heat-treated at $275^{\circ} \mathrm{C}$.

Looking at the changes in density and molar volume of $75 \mathrm{~V}_{2} \mathrm{O}_{5}-15 \mathrm{~B}_{2} \mathrm{O}_{3}-10 \mathrm{P}_{2} \mathrm{O}_{5}$ glasses shown in Figure 9, we observe that the density greatly increased and the molar volume greatly decreased after heat treatment at $275^{\circ} \mathrm{C}$. On the other hand, when the heat treatment duration was increased, the density slightly decreased and the molar volume slightly increased.

The results from Figure 9 provide indirect evidence that describes the changes in the catalytic properties. When the glass is nanocrystallized by heat treatment, its structural density is much higher compared to the annealed glass, which leads to the enhanced catalytic activity. Increasing the heat treatment duration then leads to weaker catalytic activity because the structure gradually becomes less dense.

\section{Conclusions}

The purpose of this study was to examine and verify the correlation between the changes in the catalytic and electrical properties and the structure due to the nanocrystallization of $75 \mathrm{~V}_{2} \mathrm{O}_{5}-15 \mathrm{~B}_{2} \mathrm{O}_{3}-10 \mathrm{P}_{2} \mathrm{O}_{5}$ glass containing a mix of $\mathrm{V}^{5+}$, $\mathrm{V}^{4+}, \mathrm{BO}_{4}$, and $\mathrm{BO}_{3}$. Using various equipment of structural analysis, we conformed the $\mathrm{BO}_{3}+\mathrm{VO}_{5}\left(\mathrm{~V}_{2} \mathrm{O}_{5}\right) \rightarrow \mathrm{BO}_{4}$ $+\mathrm{VO}_{4}\left(\mathrm{VO}_{2}\right)$ change in structure by nanocrystallizing and increasing the duration of heat treatment.

The changes in the catalytic properties and electrical conductivity were due to the nanocrystal structure and the state of the vanadium ions. The heat treatment used for nanocrystallization caused the electrical conductivity to increase continually; this is because the ion ratio, $\mathrm{C}$ value, approaches 0.5 owing to the transition of $\mathrm{V}^{5+}$ to $\mathrm{V}^{4+}$. On the other hand, after being improved for the purpose of nanocrystallization, the catalytic effect decreased as the duration of heat treatment increased. This is because, during nanocrystallization, the glass structure is dense and the tunneling effect occurs more actively. This behavior accelerates the reaction responsible for the catalytic activity. However, by increasing the duration of heat treatment, the vanadium ion valency changes from $\mathrm{V}^{5+}$ to $\mathrm{V}^{4+}$, and the activity of $\mathrm{V}^{5+}$ decreases; that is, the reduction reaction site of $\mathrm{V}^{4+}$ decreases gradually, causing the catalytic property to weaken. In addition, we indirectly and quantitatively confirmed the structural change through the increase in density and the decrease in molar volume due to nanocrystallization and the decrease in density and the increase in molar volume due to increasing the duration of heat treatment.

\section{Conflict of Interests}

The authors declare that there is no conflict of interests regarding the publication of this paper.

\section{References}

[1] L. Murawski, C. H. Chung, and J. D. Mackenzie, "Electrical properties of semiconducting oxide glasses," Journal of NonCrystalline Solids, vol. 32, no. 1-3, pp. 91-104, 1979.

[2] G. Calestani, L. Marghignani, A. Montenero, and M. Bettinelli, "DC conductivity of $\mathrm{ZnOV}_{2} \mathrm{O}_{5}$ glasses," Journal of NonCrystalline Solids, vol. 86, no. 3, pp. 285-292, 1986.

[3] Y. Kawamoto, M. Fukuzuka, Y. Ohta, and M. Imai, "Electronic conduction and glass structure in $\mathrm{V}_{2} \mathrm{O}_{5}-\mathrm{BaO}-\mathrm{K}_{2} \mathrm{O}-\mathrm{ZnO}$ glasses," Physics and Chemistry of Glasses, vol. 20, p. 54, 1979.

[4] A. M. Nassar, P. A. Moustaffa, and M. A. Salem, "Electrical properties of some vanadate semiconducting glasses," Indian Journal of Pure and Applied Physics, vol. 20, no. 5, pp. 337-340, 1982.

[5] C. H. Chung and J. D. Mackenzie, "Electrical properties of binary semiconducting oxide glasses containing 55 mole \% $\mathrm{V}_{2} \mathrm{O}_{5}$, Journal of Non-Crystalline Solids, vol. 42, no. 1-3, pp. 357-370, 1980.

[6] K. S. Han, C. W. Hwang, D. H. Kim et al., "Effects of substituting $\mathrm{B}_{2} \mathrm{O}_{3}$ for $\mathrm{P}_{2} \mathrm{O}_{5}$ on the structures and properties of $\mathrm{V}_{2} \mathrm{O}_{5}-\mathrm{P}_{2} \mathrm{O}_{5}$ 
glass systems," Electronic Materials Letters, vol. 8, no. 6, pp. 655658, 2012.

[7] L. Chen, B. Yang, X. Zhang, W. Dong, and K. Cao, "Methane oxidation over a $\mathrm{V}_{2} \mathrm{O}_{5}$ catalyst in the liquid phase," Energy and Fuels, vol. 20, no. 3, pp. 915-918, 2006.

[8] D. G. Gwoo, T. H. Kim, K. S. Han, W. G. Choi, J. H. Kim, and B. K. Ryu, "Electrical properties of crystallized 30B2O3-70V2O5 glass," Electronic Materials Letters, vol. 9, no. 3, pp. 309-313, 2013.

[9] N. J. Kim, S. H. Im, D. H. Kim, D. K. Yoon, and B. K. Ryu, "Structure and properties of borophosphate glasses," Electronic Materials Letters, vol. 6, no. 3, pp. 103-106, 2010.

[10] G. D. Khattak, A. Mekki, and M. A. Gondal, "XPS studies of pulsed laser induced surface modification of vanadium phosphate glass samples," Journal of Physics and Chemistry of Solids, vol. 74, no. 1, pp. 13-17, 2013.

[11] G. D. Khattak, A. Mekki, and L. E. Wenger, "X-ray photoelectron spectroscopy (XPS) and magnetic susceptibility studies of vanadium phosphate glasses," Journal of Non-Crystalline Solids, vol. 355, no. 43-44, pp. 2148-2155, 2009.

[12] M. Demeter, M. Neumann, and W. Reichelt, "Mixed-valence vanadium oxides studied by XPS," Surface Science, vol. 454-456, no. 1, pp. 41-44, 2000.

[13] Y. Chen, K. Xie, and Z. Liu, "XPS studies of $\mathrm{V}_{2} \mathrm{O}_{5}$ thin film at different temperatures and oxygen partial pressures," Applied Surface Science, vol. 126, no. 3-4, pp. 347-351, 1998.

[14] J. Mendialdua, R. Casanova, and Y. Barbaux, "XPS studies of $\mathrm{V}_{2} \mathrm{O}_{5}, \mathrm{~V}_{6} \mathrm{O}_{13}, \mathrm{VO}_{2}$ and $\mathrm{V}_{2} \mathrm{O}_{3}$," Journal of Electron Spectroscopy and Related Phenomena, vol. 71, no. 3, pp. 249-261, 1995.

[15] A. Mekkia, G. D. Khattaka, and L. E. Wengerb, "XPS and magnetic studies of vanadium tellurite glasses," Journal of Electron Spectroscopy and Related Phenomena, vol. 175, no. 1-3, pp. 21-26, 2009.

[16] E. I. Kamitsos, M. A. Karakassides, and G. D. Chryssikos, "Vibrational spectra of magnesium-sodium-borate glasses. 2. Raman and mid-infrared investigation of the network structure," Journal of Physical Chemistry, vol. 91, no. 5, pp. 1073-1079, 1987.

[17] S. G. Motke, S. P. Yawale, and S. S. Yawale, "Infrared spectra of zinc doped lead borate glasses," Bulletin of Materials Science, vol. 25, no. 1, pp. 75-78, 2002.

[18] B. K. Sharma, D. C. Dube, and A. Mansingh, "Preparation and characterisation of $\mathrm{V}_{2} \mathrm{O}_{5}-\mathrm{B}_{2} \mathrm{O}_{3}$ glasses," Journal of NonCrystalline Solids, vol. 65, no. 1, pp. 39-51, 1984.

[19] A. Abd-El-Moneim, "DTA and IR absorption spectra of vanadium tellurite glasses," Materials Chemistry and Physics, vol. 73, no. 2-3, pp. 318-322, 2002.

[20] A. A. Alemi, H. Sedghi, A. R. Mirmohseni, and V. Golsanamlu, "Synthesis and characterization of cadmium doped lead-borate glasses," Bulletin of Materials Science, vol. 29, no. 1, pp. 55-58, 2006.

[21] Y. D. Yiannopoulos, G. D. Chryssikos, and E. I. Kamitsos, "Structure and properties of alkaline earth borate glasses," Physics and Chemistry of Glasses, vol. 42, no. 3, pp. 164-172, 2001.

[22] E. E. Horopanitis, G. Perentzis, A. Beck, L. Guczi, G. Peto, and L. Papadimitriou, "Correlation between structural and electrical properties of heavily lithiated boron oxide solid electrolytes," Journal of Non-Crystalline Solids, vol. 354, no. 2-9, pp. 374-379, 2008.

[23] A. Makishima and J. D. Mackenzie, "Calculation of bulk modulus, shear modulus and Poisson's ratio of glass," Journal of Non-Crystalline Solids, vol. 17, no. 2, pp. 147-157, 1975.
[24] K. Morinaga and S. Fujino, "Preparation and properties of SnO$\mathrm{SnCl}_{2}-\mathrm{P}_{2} \mathrm{O}_{5}$ glass," Journal of Non-Crystalline Solids, vol. 282, no. 1, pp. 118-124, 2001. 

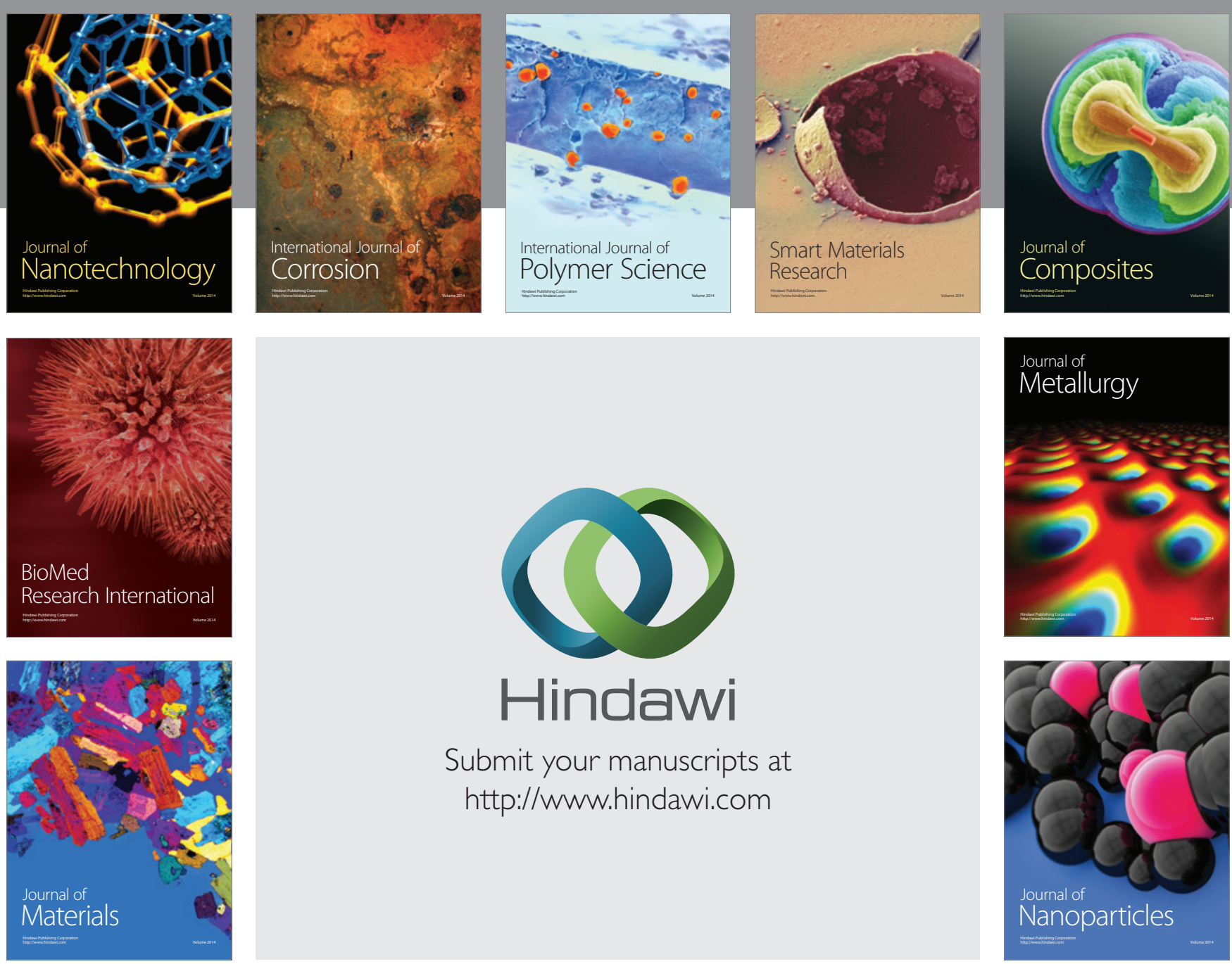

Submit your manuscripts at http://www.hindawi.com
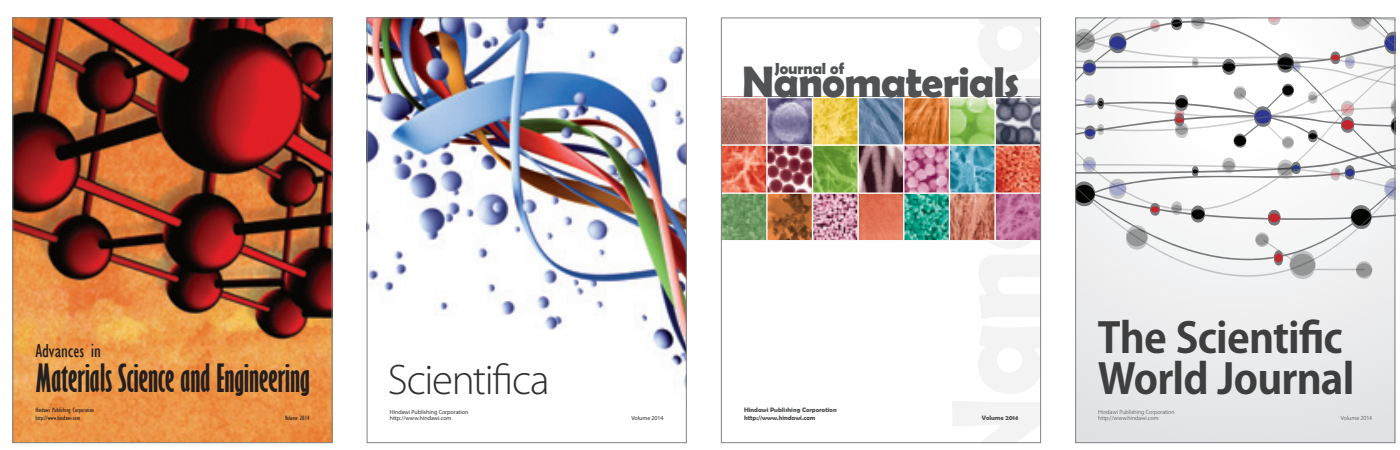

\section{The Scientific World Journal}
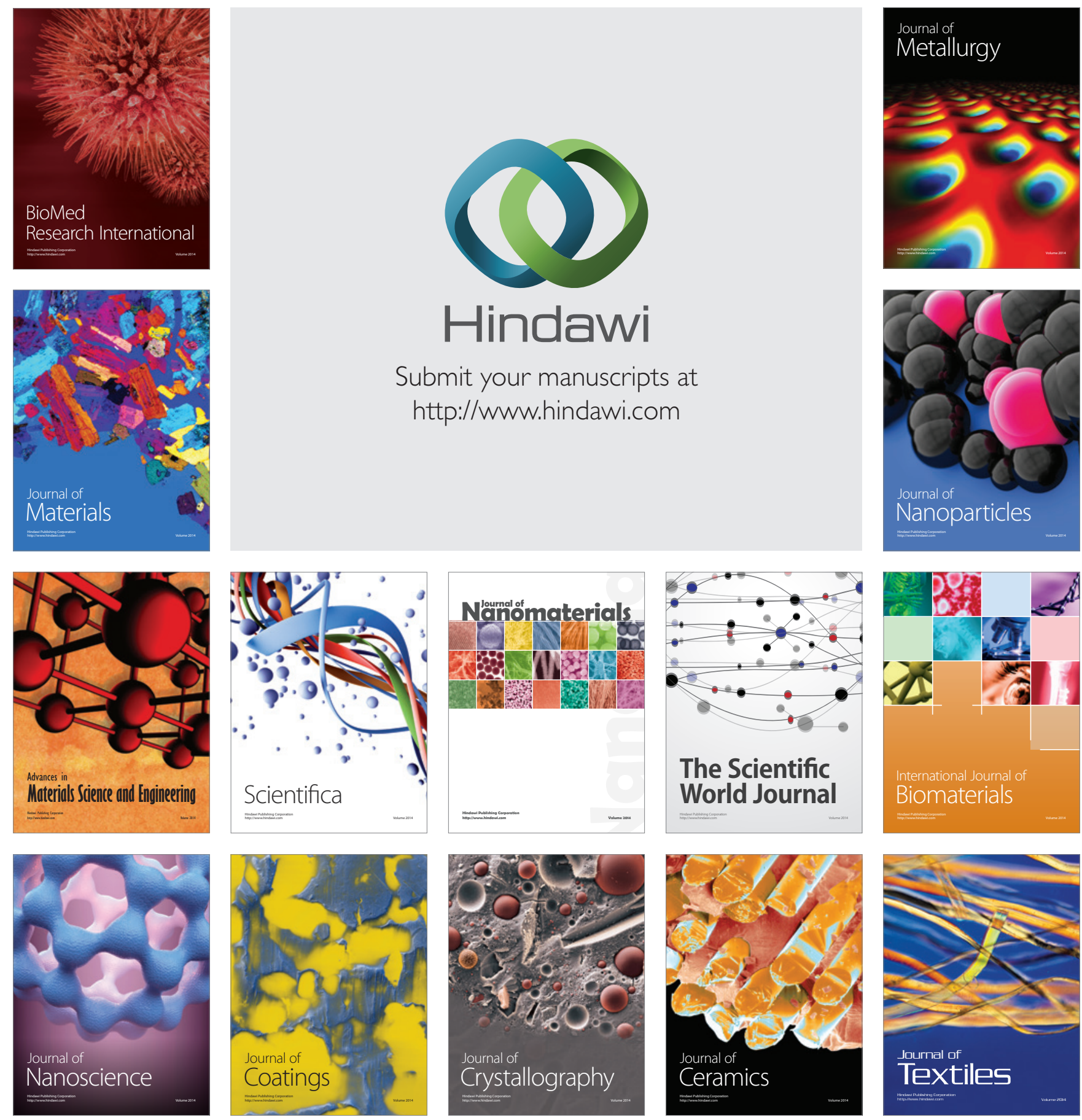